(C) 1982 ISIJ

\title{
モデル実験による融着帯形成挙動の研究
}

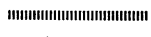

論 文

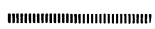

\author{
入田 俊幸*. 磯山 正*.原 義明* \\ 奥野 嘉雄* ·金山 有治*2 . 田代 清*
}

\section{Model Experiment on the Formation of the Cohesive Zone in the Blast Furnace}

\author{
Toshiyuki IRITA, Masashi Isoyama, Yoshiaki HARA \\ Yoshio OKuno, Yuji Kanayama, and Kiyoshi TAshiro
}

\begin{abstract}
Synopsis :
In order to clarify the dynamic behavior of the cohesive zone in the blast furnace, a simulation model experiment was carried out.

One-sixth scale sector model unit was built. Quasi ore and coke were charged at the top and hot air $\left(180^{\circ} \mathrm{C}\right)$ was injected from the tuyeres. The formation process of the cohesive zone was observed via a glass wall fitted on the front of the unit.

(1) The cohesive zone is found to be classified into inverted U, inverted V and normal W types, each of which seems to be attributable to the characteristics of gas flow around the root of the cohesive zone. Among them, inverted $\mathrm{V}$ type is most desirable for its efficient heat exchange and low thermal load.

(2) As concerns burden distribution, a high ore/coke ratio in the periphery makes the cohesive zone inverted $\mathrm{U}$ type and a low ore/coke ratio results in $\mathrm{W}$ type. In order to obtain inverted $\mathrm{V}$ type, an appropriate permeability of the root, especially at the wall side, is necessary.

(3) The cohesive zone tends to become inverted $U$ type with a decrease in the thermal flow ratio. An increase in the blast volume raises the level of the cohesive zone and causes its width to become broad. The permeability of the cohesive layers also exerts a large effect on their formation.

The mechanism of the cohesive-zone formation has been discussed.
\end{abstract}

\section{1. 緒言}

昭和 40 年代後半を中心に多数の高炉で解体調查が行 われ, 融着帯の存在が確かめられた1). その後の研究に より, 融着帯は炉内のガ火分配に重要な役割をはたし, 高炉プロ七火全体を左右する重要な鍵子認識され2)，高 炉の操業技術にも大きな転換をもたらした ${ }^{3)}$. しかし， 融着帯の炉内挙動に関しては, 特に重要と考兄られる根 部の挙動を中心として, 以トの点が必ずしも明らかでな i.

（1）融着带根部の位置（高さ）と厚さ（融着層枚 数〉が装入物分布とともにどら変化するか.

(2) 炉体損耗などによる炉壁際混合層の発生が，こ の根部の形成にどう影響するか.

（3）融着带や根部の形状は, 熱流比や送風量などの 操業要因とどらいう関係にあるか.

(4) 融着層にガスは流れるのかどらか. 鉱石の高温
性状（溶融時の通気性）とともに融着帯形状はどう変わ るか.

以上のことを解明するため, $200^{\circ} \mathrm{C}$ 以下の低温溶融乇 デル実験4)により, 擬似融着帯を形成させ，その挙動を 調査した.

\section{2. 実 験 方 法}

\section{$2 \cdot 1$ 溶融モデル実験装置}

モデル装置は，高炉と相似なプロフィールをもつ扇型 モデルで（室蘭 4 高炉の $1 / 6$, ただし, 炉胸の上半部を 省略, Fig. 1), 前面の透明壁から内部が観察できる. 炉頂では，ベルとムーバブルアーマーで，装入物分布を 調整する. 羽口からは加熱空気が吹き込まれ，炉内の二 ークスは金網の排出板に沿つてレースウェイの下方に排 出される. 装置の前面と背面は断熱構造とし, 本来の炉 壁に相当する側壁は, 羽口部から上方への熱伝導のみを 妨げる構造にしている．側壁と背面壁の全面に温度計と

昭和 55 年 10 月本会講演大会にて発表 昭和 57 年 3 月 18 日受付 (Received Mar. 18, 1982)

* 新日本製鉄 (株)室蘭製鉄所 (Muroran Works, Nippon Steel Corp., 12 Nakamachi Muroran 050)

* 新日本製鉄 (株) 军蘭製鉄所 (現：新日本製鉄 (株) 本社) (Muroran Works, Now Head Office, Nippon Steel Corp.) 
Table 1. Phyisical properties of experimental burden.

\begin{tabular}{|c|c|c|c|c|c|c|c|c|}
\hline & \multirow{2}{*}{$\begin{array}{l}\text { Particle } \\
\text { size mm }\end{array}$} & \multirow{2}{*}{$\begin{array}{l}\text { Bulk density } \\
\mathrm{kg} / \mathrm{m}^{3} \text {-bed }\end{array}$} & \multirow{2}{*}{$\begin{array}{c}\text { Voidage } \\
\mathrm{m}^{3} / \mathrm{m}^{3} \text {-bed }\end{array}$} & \multirow{2}{*}{$\begin{array}{l}\text { Specific heat } \\
\mathrm{kcal} / \mathrm{kg} \cdot \mathrm{K} \\
\left(30^{\circ} \mathrm{C}\right)\end{array}$} & \multirow{2}{*}{$\begin{array}{l}\text { Heat of fu- } \\
\text { sion } \\
\mathrm{kcal} / \mathrm{kg}\end{array}$} & \multicolumn{2}{|c|}{ Pressure drop mmaq } & \multirow{2}{*}{ Remarks } \\
\hline & & & & & & $\Delta P\left(20^{\circ} \mathrm{C}\right)$ & $\Delta P_{\max }\left(90^{\circ} \mathrm{C}\right)$ & \\
\hline Quasi ore & $4 \sim 7$ & 420 & 0.50 & 0.533 & 44.8 & 6 & 223 & Low m.p. alloy : $13.2 \%$ wt \\
\hline Coke & $10 \sim 15$ & 620 & 0.43 & 0.250 & - & 3 & - & Coated particles \\
\hline
\end{tabular}

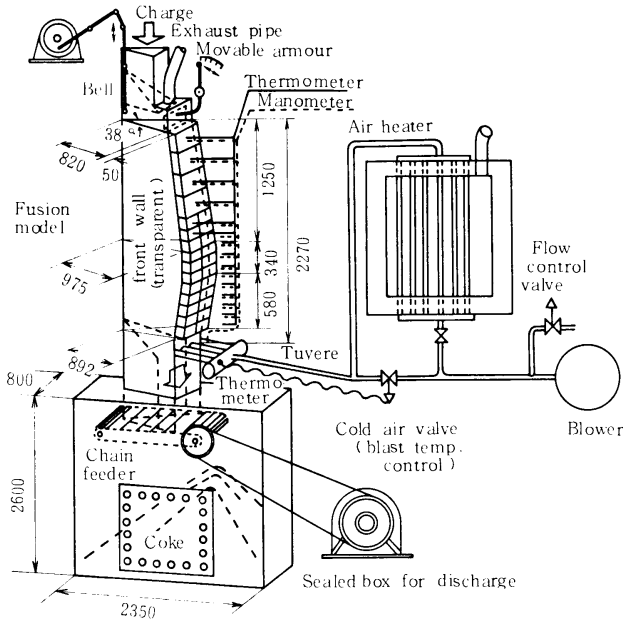

Fig. 1. Experimental apparatus.

圧力測定孔を 160 点配置し, 側壁の内側に荷重受圧板, 外側に熱流センサーを各, 数ヶ所取り付けた.

\section{$2 \cdot 2$ 装入物試料の調整}

用いた擬似鉱石とコークスの物性をTable 1 に示す. 擬似鉣石はステアリン酸系ワックスを造粒したもので, 軟化温度で白色から淡黄色へ変化し，滴下温度でほぼ透 明な液となつた。 また，荷重軟化試験でも軟化開始と滴 下終了の温度が明瞭で，実鉱石の類似の圧損パターンを 示し，その压損值はワックスの組成により調整できた (Fig. 2).このらち, 焼結鉱の特性に最も近い鉱石 Bを 実験の標準試料とした．なお，擬似鉱石には低融点合金 を核として含め，モデル装置内での粒子の流動化を防止 した.

\section{$2 \cdot 3$ 実験条件}

実験条件を Table 2 に示寸. 送風量 $9 \mathrm{Nm}^{3} / \mathrm{min}$ の とき，計算炉口風速が実炉と同等 $(1.0 \mathrm{~m} / \mathrm{s})$ である。送 風温度 $180^{\circ} \mathrm{C}$ で実炉ともモデルの温度分布が相似とな る(Fig. 3)。なお，熱流比は，コークス排出速度で調整 した.

コークスベースは, 炬内の層厚方向の粒子数から定 め, Ore $/$ Coke (以下, O/C) は, 滴下带の液量が 2 次元 フラディング 限界5)を越えない範团とした。 ここで, 実験の $\mathrm{O} / \mathrm{C}$ 值は，鉱石とコークスの蔏比重を $2.0,0.5$
Table 2. Experimental condition.

\begin{tabular}{|c|c|c|}
\hline Blast volume $\mathrm{Nm}^{3} / \mathrm{min}$ & $\begin{array}{c}\text { Standard } \\
9\end{array}$ & $\begin{array}{l}\text { Range } \\
6 \sim 12\end{array}$ \\
\hline Blast temperature $\quad{ }^{\circ} \mathrm{G}$ & 180 & $150 \sim 200$ \\
\hline Thermal flow ratio* - & 0.85 & $0.6 \sim 1.0$ \\
\hline Coke base $\quad 1 / \mathrm{ch}$ & 32 & $24 \sim 32$ \\
\hline Ore/Coke & 2.25 & $1.5 \sim 3.2$ \\
\hline
\end{tabular}

* Water equivalent flow ratio of burden to gas
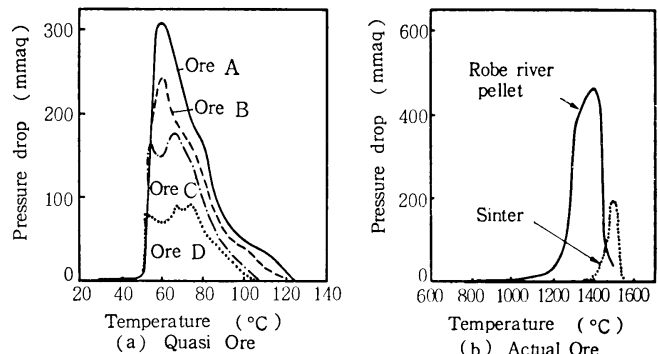

Fig. 2. Comparison between quasi ore and actual ore for the elevated temperature property.

$\mathrm{t} / \mathrm{m}^{3}$ と仮定した計算重量比である.

\section{3. 実 験 結 果}

\section{$3 \cdot 1$ 融着帯の形成}

モデル実験では，炉内の装入物が・巡すると融着带形 状がほぼ安定した．炉内各点の温度や压力が平衡に達す ると操業を終了（送風と荷降下を停止）し炉頂より散水 した。冷却後の炉内からコークス層にはさまれた岩盤状 の融着層を一枚ずつ取り出すことができたが，ての外見 は高炉解体調查で確認されたものと酷似していた（Photo. 1).

本論文では，この融着帯各部の名称を Fig. 4 のごと く定め, 以下，これを用いて融着帯の挙動を記述した。

\section{$3 \cdot 2$ 装入物分布と融着帯形状の対応}

装入物分布と融着帯形状の対応を Fig. 5 7 に示与. Fig. 5 に示されるごとく，中心部 $\mathrm{O} / \mathrm{C}$ の減少により 頂層が上昇，相対 $\mathrm{O} / \mathrm{C}$ が最大となる位监が中心側に寄 るにつれてその位置で融着帯が低トし，炉壁部 $\mathrm{O} / \mathrm{C} の$ 増大により根が上下に厚くなるなど，融着带形状は装入 物分布によつて敏感に変化した。しかし，根下端は羽口 に近い低位置からほとんど動かず，炉壁部 $\mathrm{O} / \mathrm{C}$ の減少 


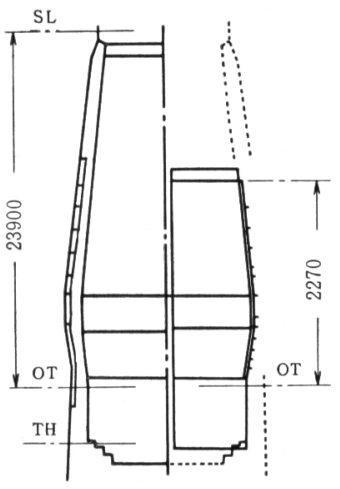

Blast furnace
Model furnace

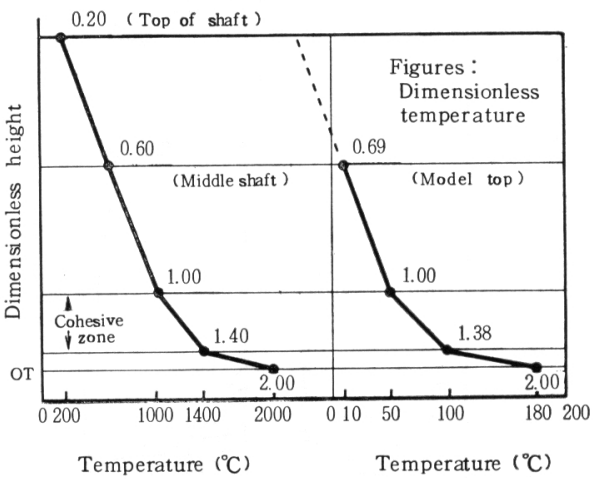

(a) Blast furnace

(b) Model furnace

Fig. 3. Similarity in temperature distribution.

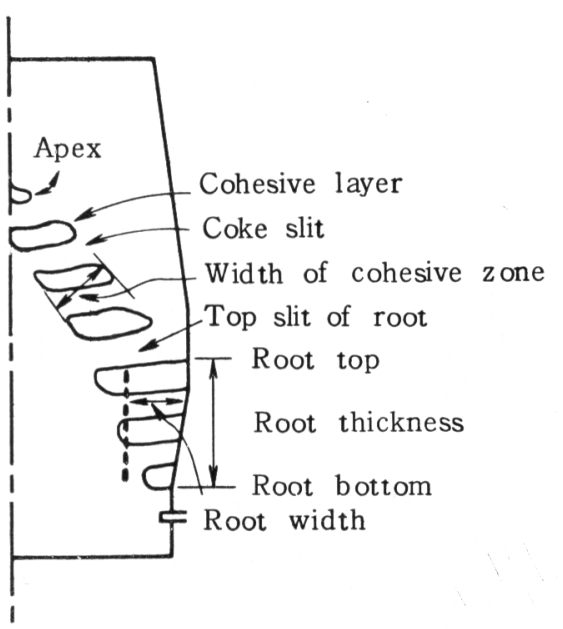

Fig. 4. Denomination of each part of the cohesive zone.

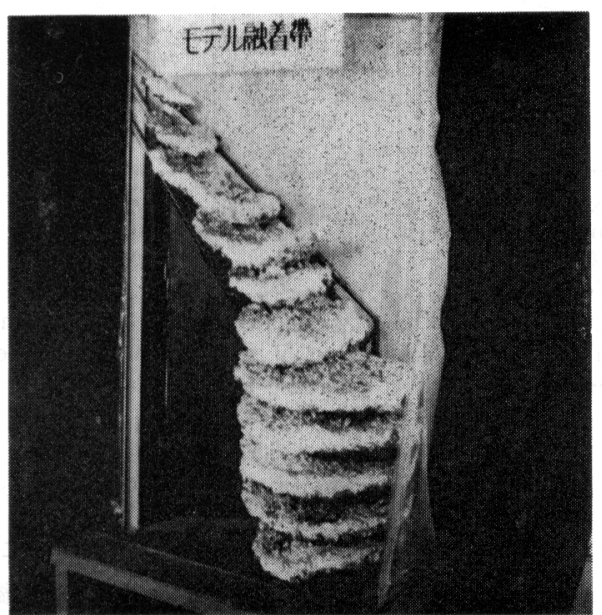

Photo. 1. The model cohesive zone.
に伴い根上端が低下した。こうして融着帯は概して中心 流型の形状のまま, 主として根の厚みが変化した。 しか し, 炉壁部 $\mathrm{O} / \mathrm{G}$ を極端に減少すると融着帯はW型化 し，根上端が上昇した (Fig. 6).な牧，以上のアーマー 操作の他に装入方式も大きく変更した. Fig. 7 は装入 物の層厚を半分にしたもので, 高熱流比にもかかわらず 融着帯レベルが高く, 逆に根部は付着物状に炉壁部で溶 け残りその下端は低くなつた。 また，鉱石とコークスを ベル上で均一に混合して装入した場合もこれと全く同じ 形状の融着帯になつたが，その中には根下端が羽口の下 まで達するものもあつた。

\section{$3 \cdot 3$ 炉壁際混合層の形成による融着帯根部の変化}

シャフト下段の炉壁内面から邪魔板を突き出し, 炉壁 際に混合層を形成させた。 Fig. 8 に示すように, 邪魔 板を $20 \mathrm{~mm}$ 突き出すことにより根の下端が上昇, 上端

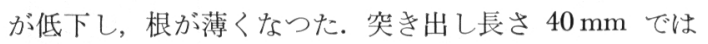
根が更に薄くなる傾向を示したが, 安定に至る前に根部 の円周バランスが崩れた。な扣邪魔板によらず, アーマ 一操作でごく炉壁際の $\mathrm{O} / \mathrm{G}$ 老減少した場合にも根の下 端が上昇した (Fig. 9)。

\section{$3 \cdot 4$ 熱流比による融着帯形状の変化}

熱流比之融着帯形状の関係を Fig. 10 に示す. 図の ごとく熱流比の減少とともに融着帯上面 (頂層 根上 端）が上昇した. しかしこの時も根下端の上昇は鈍く, 根の厚みが著しく増加した. な怔, 実験中の変化とし て, 低熱流比条件では, まず根上端のすぐ上の融着層 (その炉壁側に鉱石粒子層が連なる) の久が炉壁の方に 向かつて急速に成長（融着が進行）し，それが炉壁まで 達すると（すなわち根部になると）, つづいて，そのす ぐ上の融着層が同じように急速な成長を開始するという 具合にして根部が 1 枚ずつ殖光, みるみるうちに厚い根 


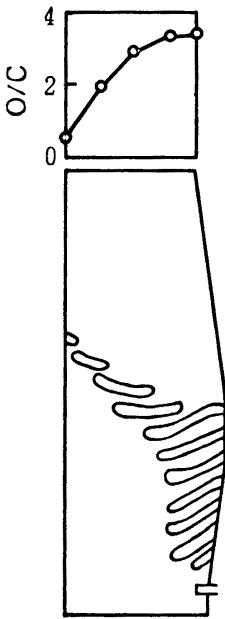

(a) $\mathrm{O} / \mathrm{C} 2.8$

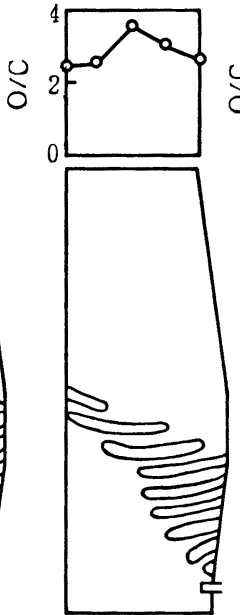

(b) $\mathrm{O} / \mathrm{C} 3.0$

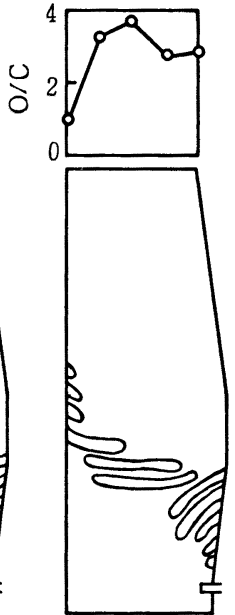

(c) $\mathrm{O} / \mathrm{C} 3.2$

Operational BV (blast volume) $12 \mathrm{Nm}^{3} / \mathrm{min}$ condition BT (blast temperature) $180^{\circ} \mathrm{C}$ TR (thermal flow ratio) 0.85 -

Fig. 5. Relationship between burden distribution and the shape of the cohesive zone.

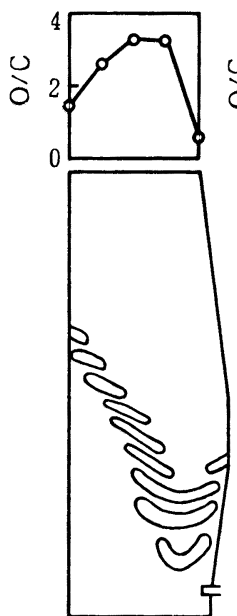

(a) $\mathrm{BV} 12 \mathrm{Nm}^{3}$

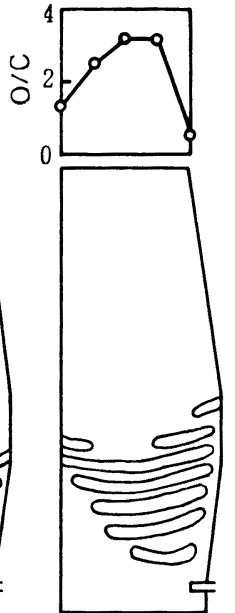

(b) $\mathrm{BV} 8 \mathrm{Nm}^{3}$

\section{Operational BT $180^{\circ} \mathrm{C}$}

condition TR 0.80 $\mathrm{O} / \mathrm{C} \quad 2.3-$

Fig. 6. Burden distribution and $\mathrm{W}$ shaped cohesive zone.

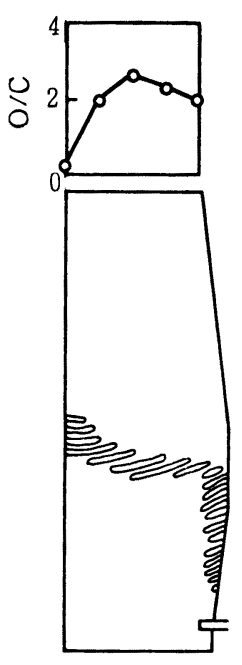

Operational condition

BV $9 \mathrm{Nm}^{3} / \mathrm{min}$
BT $180^{\circ} \mathrm{C}$ TR $0.95-$ O/C 2.3-

Fig. 7. Cohesive zone formed with half layer thickness.
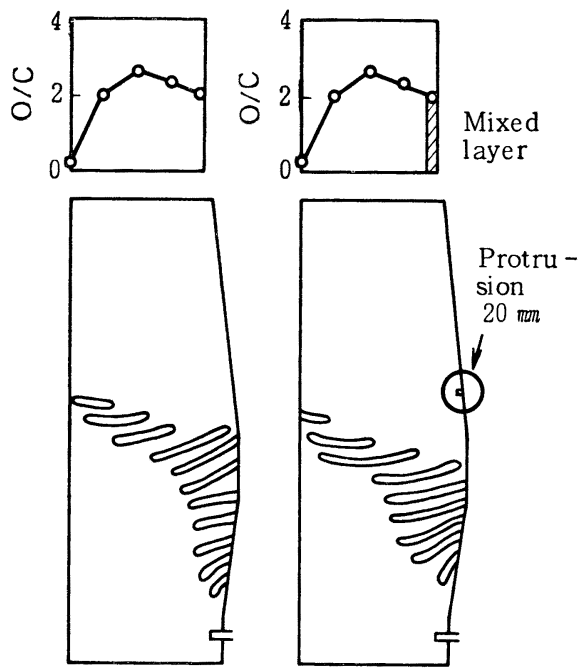

Operational BV $11 \mathrm{Nm}^{3} / \mathrm{min}$ condition $\mathrm{BT} 180^{\circ} \mathrm{C}$ TR 0.85 $\mathrm{O} / \mathrm{C}: 2.3-$
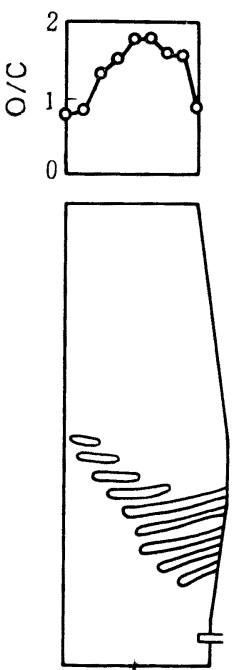

Operational BV $6 \mathrm{Nm}^{3} / \mathrm{min}$ condition $\mathrm{BT} 180^{\circ} \mathrm{C}$ TR 0.68 $\mathrm{O} / \mathrm{C}$ 1.5-
Fig. 8. Influence of the mixed Fig. 9. Ascent of the root bottom layer at the wall on the of inverted $\mathrm{V}$ shaped cohesive zone formation of the cohesive zone. by a decrease in $\mathrm{O} / \mathrm{C}$ at the wall side.
が形成された。この根上端の上昇は，明らかに，根上端 のスリットコークス層からの強い高温ガス流によりもた らされたものである．屯た，この後，熱流比を高いレべ ルに変更しても根の原みは容易に減少せず，融着帯の上
面とともに厚い根が低下し，その下端がレースウェイに 接触して崩壊した（多くの場合，そのま操業不調に陥 つた)。このように，根部は一旦肥大化するとその制御 性が著しく低トした。 
Ope rational

condition

BV $9 \mathrm{Nm}^{3} / \mathrm{min}$

BT $180^{\circ} \mathrm{C}$

$\mathrm{O} / \mathrm{C} 2.3$ -

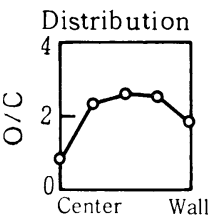

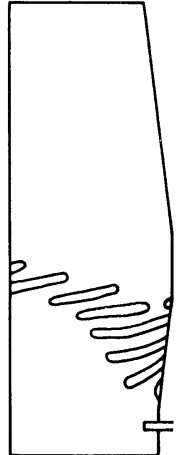

0.85

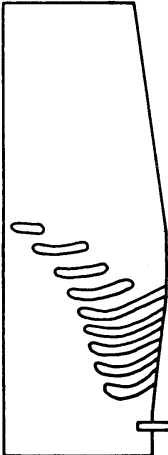

0.79

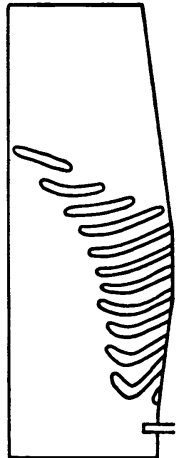

0.71
Fig. 10. Relationship between the thermal flow ratio and the shape of the cohesive zone.

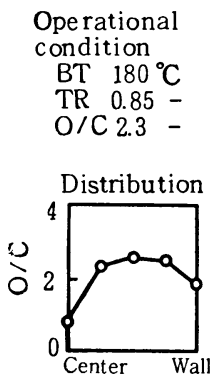

Blast volume

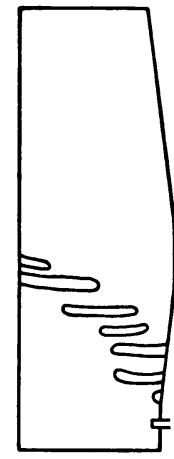

$7 \mathrm{Nm}^{3} / \min$

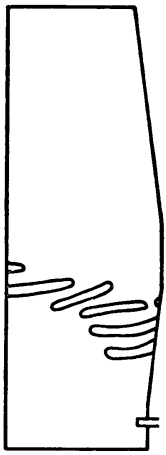

$9 \mathrm{Nm}^{3} / \mathrm{min}$.

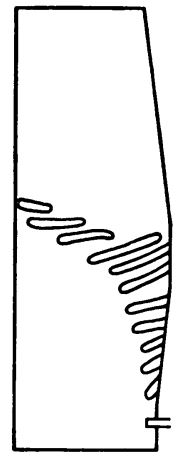

$11 \mathrm{Nm}^{3} / \min$.

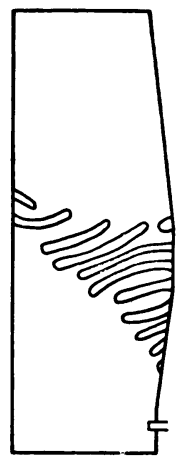

$13 \mathrm{Nm}^{3} / \mathrm{min}$

Fig. 11. Relationship between the blast volume and the shape of the cohesive zone.

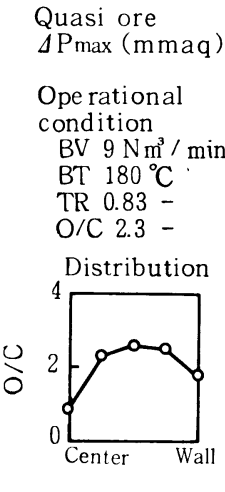

Blast press.

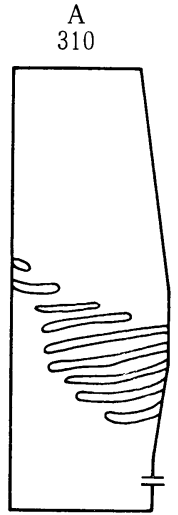

891

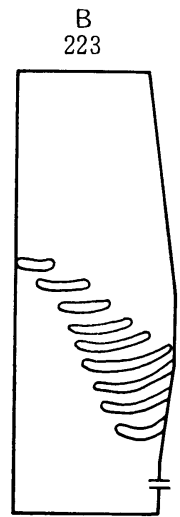

800

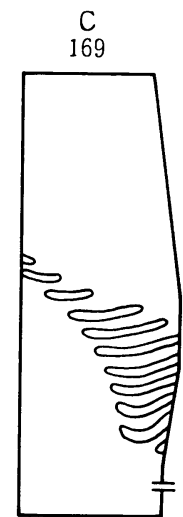

703

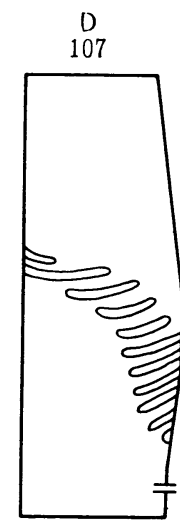

579

Fig. 12. Effect of the high temperature property of the quasi ore on the formation of the cohesive zone. 


\section{5 送風量と融着帯形状の対応}

熱流比を一定に保つて送風量を変更した，送風量の増 加とともに融着带が上昇し，その幅（融着開始面～滴下 面間距離）が全体に広がつた（Fig. 11）。

W型融着带の場合には送風量が減ると周辺ガス流が強 くなり，融着带形状が著しく変化した（Fig. 6).

\section{7 鉱石の高温性状と融着帯形状の対応}

擬似鉣石 $\mathrm{A} \sim \mathrm{D}$ (Fig. 2) を用いて実験を行つた。擬 似鉱石の特性により融着帯形状や送風圧力が著しく変化 した（Fig. 12)。融着時圧損の高い鉱石では根部が炬芯 側に大きく張り出し, また, 他より滴下温度が高いにも かかわらず(Fig. 2), 根下端の位置が高かつた。しかし 圧損の低い鉱石では融着带の幅が狭く, 炉の中間部で融 着帯が溶け上がり根が炉壁部で溶け残る傾向を示した。

これらは, 融着層の通気性がその加熱と溶解飞強く影 響し，融着帯形状を大きく変化させることを示す。

\section{4. 考察}

\section{$4 \cdot 1$ 装入物分布と融着帯形状の関係}

一般に, 融着带の各部は, 炉径方向でのその位置の相 対 $\mathrm{O} / \mathrm{C}$ 比の減少により上昇する. これは, 相対 $\mathrm{O} / \mathrm{C}$ 分布が塊状帯での熱流比分布を強く支配するためである (特にモデル実験では，装入物の粒度範囲が狭いため, 粒度偏析の影響が無視できた)。このことから，O/C が 中心部で低く炉壁部で高い分布が，逆 V型融着帯に対応 すると考学がちである。しかし実験では，炉壁部の $\mathrm{O} / \mathrm{C}$ を最も高くすると必ず根が厚くなり, 融着帯が逆U型化 した，根の肥大が無い逆 $\mathrm{V}$ 型融着带を得るには， O/C 分布を炉壁部で低く，その少し炣内側で最も高くする必 要があつた (Fig. 9).このように，根部のレベルでは 炉芯側にコークスしか存在しないため根の溶解にかかわ
る炉下部のガス流分布は塊状帯の $\mathrm{O} / \mathrm{C}$ 分布之直接関係 しない (cf. Fig. 14).

炉内ガス流による根の形成・溶解機構として， Fig. 13 に示す 3 つのケースを考光る必要がある。（a）は， 炉壁部 $\mathrm{O} / \mathrm{C}$ が過大などの理由により根の通気が悪い場 合である.滴下带を上昇した高温が久が根上端入リット から炉壁部の方へ吹きつけ, 根は上方汁大し, 融着带 は逆U型化する。（b ）は根の通笳が保たれている，根の 内部で熱交換が行われ，熱を失つたがスが塊状带の炉壁 部に達する。根の上端は下がるが，根内部の昇温は最も スムースに進みその厚さが減少する。融着带は逆 $\mathrm{V}$ 型 になる。（c）は，炉壁部での融着層の形成が不完全であ る。その内側で融着帯が垂れトがり，(a)の場合と同 様，コークス带からのガスが直接塊状带へ抜け，既滆 着した部分が肥大化する。融着带はW型である.

以上のらち, 逆 $\mathrm{V}$ 型融着带の根部が最も薄く, 㕕い塊 状带を確保するのに適している。

\section{$4 \cdot 2$ 壁際混合層と根の溶け落ち}

一般に融着層の通気性を改善しても根部の炉壁際は溶 けにくく，かえつて根下端は低くなる。この現象は，装 入物の層厚が不十分な場合や，鉱不・コークスの潉合 物，あるいは融着時圧損の低い鉱石を装人した奉験のす べてに共通していた。しかし，壁際混合層の形成によ り，根下端が上昇し根の厚さが減少した。これは，炉壁 際での通気改善により, 根内部のコーク火層がある程度 スリットとして機能し根全体のスムーズな界温を促した ためと考觉られる。

\section{3 熱流比による融着帯形状の変化}

熱流比の減少により融着帯の上面が上界したが、これ は向流熱交換プロセスに括いて然な現象である。とこ ろがこの時, 根下端は上开せず融着带は逆U型化しだ。

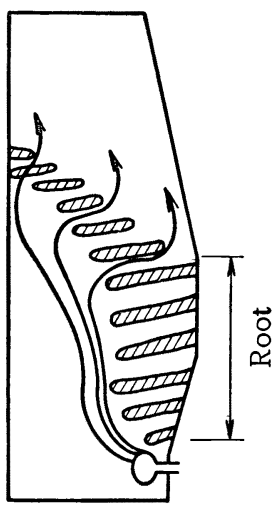

(a) Inverted $\mathrm{U}$ type

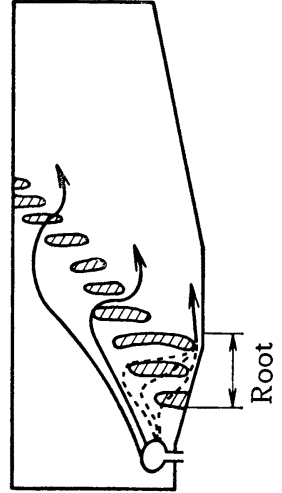

(b) Inverted $\mathrm{V}$ type

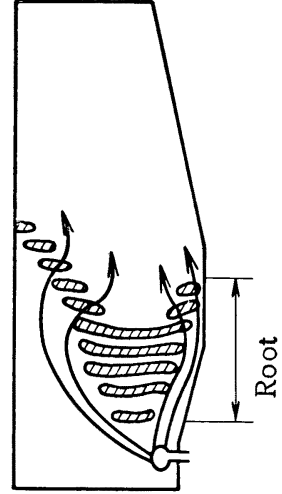

(c) W type
Fig. 13. Formation of three typical shape of the cohesive zone attributable to the characteristics of the root melting in gas flow. 

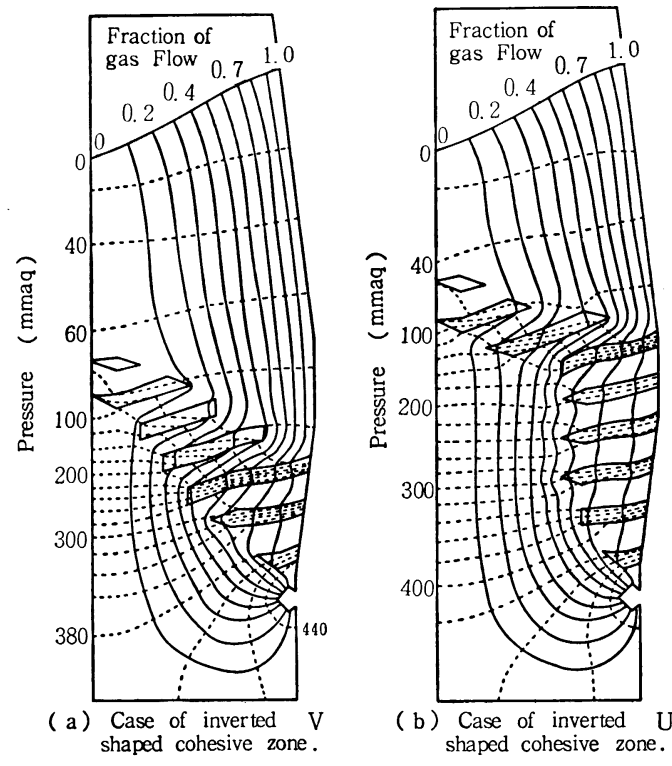

(b) Case of inverted U shaped cohesive zone. $\left.{ }_{0}^{0.3}\right)^{0.3} \cdot \mathrm{K} \cdot \mathrm{G}^{1.7}$

Pressure drop equation $\frac{\Delta \mathrm{P}}{\mathrm{L}}=\frac{\left(\mu / \mu_{0}\right)}{\left(\rho / \rho_{0}\right)} \cdot \mathrm{K} \cdot \mathrm{G}$

$\begin{array}{rlll}\text { Permeability resistance }: & \text { Kc ( coke ) } & =100 \\ & \text { Ko (lumpy ore ) }=150\end{array}$

Kf ( cohesive layer $)=7500$

Kd (dropping zone) $=200$

Fig. 14. Relation between the shape of the cohesive zone and the gas flow.

これには根部のガ久流量が関係しているものと思われ る. Fig. 14 は, 逆 V型, 逆U型融着带におけるガス流 れを有限要素法により計算したものである. 融着層の通 気抵抗を塊状時の 50 倍として与えている. 図で, 根部 は炉の水平断面積の 7 割以上を占めるが 3 割のガスしか 流れていない。ここで仅に平均熱流比を 0.85 とする と, 根部での熱流比は 2.0 (滴下帯側は 0.32) と求めら れる.このように根部は極端に熱流比が高く、いわば向 流交換プロセ久から取り残されたまま降ドし, 羽口付近 の高温・高流速のガ久に触れて急速に溶かされる部分で ある (Fig. 5〜6は, 融着帯の形状が著しく異なるもの でも融着带の下端レベルがあまり変わらないことを示す が,このように根部のト限は, 羽口を含さ高炉の構造に もとついて大きく規定されるものと思われる).

このように，根ト端が上算しにくいのは一種の高炬特 性であると考えられ，一方，根上端の上昇は塊状鉱石層 の温度上昇により生じ, 平均熱流比 (操業条件) の変化 に敏感に応答するため, 根部は急速に厚くなる。

\section{4 送風量と融着带レベルの関係}

熱流比を一定にして送風量を増すと, 融着帯が上昇し その幅が広がつた。炉内の伝熱係数の増加により, 上部 での装入物の昇温, およびト部でのガス温度の低下が急

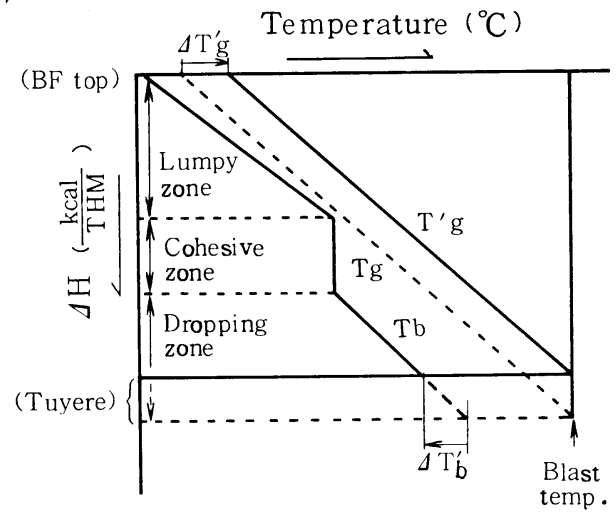

Fig. 15. Change in the difference between gas and burden temperature with an increase in the blast volume.

速化するものと予想されるが，それだけでは融着帯が上 昇することにはならない，向流熱交換において流速が大 きくなると滞留時間が減少し，高温側流体であるガスの 出口温度 (炉頂温度) が上昇, 低温側流体である装入物 の出口温度（装入物到達温度）が低下する.この時の装 入物の温度 $T_{\mathrm{b}}$ とガス温度 $T_{\mathrm{g}}$ (増風前), $T_{\mathrm{g}^{\prime}}$ (増風後) の関係は, 模式的に Fig. 15 に示される (Reichardt 線図 $\left.{ }^{6}\right)$ ）。縦軸は，装入物またはガスのエンタルピ変化て ある．両者は高炉の任意の 2 点間で一致するので同一の 縦軸にのる. 図中 $\Delta T_{\mathrm{g}^{\prime}}, \Delta T_{\mathrm{b}}{ }^{\prime}$ が前記各出口温度の変 化である，図は増風により，炉の全域でガス-装入物間 の温度差が増大することを示す．このとき，例えば，塊 状帯での温度差が 2 倍になれば，装入物が装入されてか ら融着温度に至るまでの時間はほぼ半分になると考えら れる.これに対して融着帯や滴下帯の温度差は増加率と しては小さいため, 所定の伝熱量を達成するのに要する 時間が相対的に増加する. 各帯での温度差増加率の相対 的な関係から, 塊状帯で余つた距離が, 融着帯よりも滴 下带の方に多く分配されるはずである。この結果融着带 が上昇し，その幅がいく分広くなる.

\section{5 融着層の通気性と融着帯の挙動}

従来から，融着層はガス分配板として重要であると考 えられている，例えば，モデル実験において，レースウ エイ直上に大きく張り出した融着層が溶け落ちる時の円 周バランスは極めて不安定だが，多くの場合その上の層 の溶解のバランスにはあまり影響しなかつた。これは, 炉内のすべての鉱石層, 融着層が一枚ごとにュークスの 整流層に挾まれているため，それが部分的に破れても， 径方向, 円周方向へとガス分配が安定して行われるため である。しかし，このことは必ずしも融着層にガスが流 
れないということを意味しない。

以上の考察でも述べてきたと㧍り, 実験にお斿る融着 帯の挙動は, 根部などにおける通気量が微妙に变化した と考えることにより説明しうるものであつた。 また，ガ ス流れの計算結果も，根部を貫通するガス量が決して無 視できないものであることを示し，更に，滴下带から塊 状帯へ抜けるガスが，根上端の融着層に多く流れ，根部 が逆U型に形成されやすいことを示唆している (Fig. 14).

しかし, 融着層は通気抵抗が大きいがゆえに溶け残り あるいは肥大化する.このことから, 融着層の通気抵抗 によらない炉内制御を指向する余地が残されていると思 われる，近年，鉱石の高温性状が改善され，融着層の通 気抵抗は着実に減少しつつある.これにより融着層によ くガスが流れ, 融着帯が薄くなり, 高炉の効率が高まる はずである. しかし同時に, 層状充塤構造にもとづくが スの整流作用は相対的に弱まり, 融着帯の形状や周方向 の均一性が特にその下部において不安定化する.こうし て, 鉱石の高温性状が改善されるほど, 炬頂装入物分布 の調整にますます高い制御精度が求められることになる ものと思われる。

\section{5. 結}

\section{論}

鉄鉱石の融着挙動をシミュレートしうる擬似鉱石を用 い, 高炉と相似な縮尺実験装置で融着帯を形成させ, 装 入・送風条件との対応を実験的に把握し, その挙動につ いて考察した.

（1）融着帯は, 根部の形態により, 逆U型, 逆 $\mathrm{V}$ 型, W型に分類される. そのうちで, 制御性に優れ, 炉 の伝熱効率もよく, 炉体熱負荷の低い逆 $\mathrm{V}$ 型が最も望ま しい.
（2）中心流を指向する操業において, 融着帯は操業 条件の変化により逆U型化する傾问が強い。これを逆 $\mathrm{V}$ 型にするには, 炉壁部と, 特にその炉壁際で, 適度な通 気を確保することが重要である.

（3）炉壁祭の通気性は，炉壁部 $\mathrm{O} / \mathrm{C}$ のほか，炉壁 際の混合層の有無によつても变化する.

（4）送風量の増加や熱流比の低卜により融着带が上 昇する，ただし，炉壁部に適度な通父が確保されない場 合は根下端のみ上昇せず, シャフト下部への熱負荷を増 しながら融着帯上面のみが大きく、昇し, 逆U型融着帯 となる。

（5）逆U型融着帯の制御性は忠く，特にその根が厚 いものは熱流比の増加により根が厚いまま容易に低下 し, 操業不調に結びつく.

（6）炉内ガスの--部は融着層を貫通し，その量が融 着層の加熱 ·溶解に顕著な影響を方える．融着時圧損の 高い鉱石を用いた場合には，融着層幅や根の張り出し幅 が著しく増加する.

\section{交献}

1 ) 近滕真一：製銑技術の最近の諸開題（第33・34回 西山記念技術講座) (1975)，p.125 [日本鉄鋼協 会]

2) 会. Togino: Coal, Coke and the blast furnace Jun. (1977) [Metal Sociaty]

3 ) 研野雄二, 楯岡正殸, 須賀田正泰, 山口一成, 久 米正一, 山口一良, 安倍 勲: 鉄と鋼, 65 (1979) 10, p. 1553

4) S. Wakayama, $Y$. Kanayama, and $Y$. OKuno: Ironmaking and Steelmaking (1979) 6, p. 261

5 ) $N$. Standish, and $L$. Colquhoun: Blast Furnace Aerodynamics, ed. by $N$. STANDish (1975), p. 20 [Australian Inst. Min. Met.]

6 ) P. Reichardt: Arch. Eisenhüttenw., 1 (1927), p. 77 